\title{
Artikel
}

\section{Contempt of court als inspiratiebron voor de Nederlandse strafrechtspleging}

\author{
Mr. dr. M. (Marianne) Lochs*
}

NTS 2020/27

\section{Inleiding}

In Nederland is de afgelopen jaren met enige regelmaat gesuggereerd dat er behoefte zou bestaan aan een instrument als het Angelsaksische contempt of court. Het werd genoemd na de verwikkelingen in het Wildersproces, ${ }^{1}$ als middel om misbruik van wraking tegen te gaan, ${ }^{2}$ en zou meer in zijn algemeenheid een instrument zijn waarmee kan worden opgetreden tegen ondermijning van het gezag van de rechter. ${ }^{3}$ Hoewel dus zeker de laatste jaren in nogal uiteenlopende contexten wordt gesteld dat contempt of court een oplossing zou kunnen zijn voor ontwikkelingen waarvoor de rechter zich in toenemende mate gesteld ziet, wordt er nauwelijks discussie gevoerd over de betekenis en reikwijdte van het begrip en wat men er nu eigenlijk van kan verwachten. ${ }^{4}$ In dit artikel wordt uiteengezet wat contempt of court is, en wordt ingegaan op de vraag of het instrument een zinvolle bijdrage kan leveren aan de waarborging van een goede strafrechtspleging in Nederland. Het artikel is een bewerking van het proefschrift Contempt of court. Een

Mr. dr. M. Lochs is advocaat bij Spong Advocaten te Amsterdam.

1. In het interview met oud-rechter Salomons, 'De rechter met de boodschappentas', NRC 23 december 2016.

2. M.S. Groenhuijsen, 'Wraking over individuele rechtsbescherming en bescherming van de integriteit van de strafrechtsbedeling', DD 2017/8, afl. 2, p. 67-76.

3. Voordracht G.J.M. Corstens, uitgesproken op 30 augustus 2011 bij de discussiebijeenkomst 'Rechters van deze tijd', georganiseerd door het Montesquieu Instituut.

4. Een belangrijke aanzet daartoe is wel gegeven door N. Keijzer, Contempt of court (afscheidsrede Tilburg), Deventer: Kluwer 2000. meermaarde voor de goede strafrechtspleging in Nederland? en geeft een beknopt overzicht van de belangrijkste bevindingen uit het proefschrift. ${ }^{5}$

\section{Inhoud en betekenis van contempt of court}

Contempt of court is in de twaalfde eeuw ontstaan in Engeland en heeft zich in de common law ontwikkeld als middel om op te treden tegen een groot scala aan gedragingen waarmee de goede rechtspleging kan worden verstoord of belemmerd. ${ }^{6}$ Het begrip betekent letterlijk 'minachting van het gerecht', maar wordt tegenwoordig vooral gezien als een instrument waarmee de 'due administration of justice' wordt gewaarborgd en niet in de eerste plaats de eer of goede naam van de rechter. ${ }^{7}$ In een vaak geciteerde uitspraak uit 1923 werd het begrip als volgt gedefinieerd: 'The offence consists in interfering with the administration of the law; in impeding and perverting the course of justice. It is not the dignity of the Court which is offended (...) it is the fundamental supremacy of the law which is challenged.' ${ }^{8}$ Het wordt beschouwd als een inherente bevoegdheid die voorondersteld wordt bij rechtsprekende organen en die nood-

5. M. Lochs, Contempt of court. Een meerwaarde voor de goede strafrechtspleging in Nederland? (diss. Leiden), Den Haag: Boom juridisch 2019.

6. Zie over de geschiedenis van contempt J.C. Fox, The history of contempt of court. The form of trial and the mode of punishment, Abingdon: Professional Books Unlimited 1972 (oorspronkelijk werk gepubliceerd in 1927). In Engeland en Wales is contempt of court tegenwoordig deels gecodificeerd met de Contempt of Court Act 1981.

7. I. Cram, Borrie and Lowe: The Law of Contempt (4th Edition), Londen: Lexis Nexis 2010, p. 1

8. Lord President Clyde in Johnson v. Grant [1923] SC 789. 
zakelijk is voor hun goede functioneren. Contempt of court is in alle Angelsaksische rechtstelsels te vinden, hoewel de invulling van land tot land verschilt. ${ }^{9}$

Van oudsher wordt doorgaans een onderscheid gemaakt tussen criminal en civil contempt of court. Gedragingen die als strafrechtelijke contempt of court worden beschouwd vormen een zodanige bedreiging voor de rechtspleging dat een openbare bestraffing noodzakelijk is: contempt of court fungeert dan als strafbepaling om op te treden tegen bijvoorbeeld verstoringen van de orde op de zitting, weigerachtige getuigen of publicaties die een eerlijke rechtsgang kunnen beïnvloeden. Civil contempt of court daarentegen is het niet-naleven van een rechterlijke uitspraak of bevel, waarbij het opleggen van een sanctie (doorgaans een geldboete of hechtenis) vooral als een dwangmaatregel wordt beschouwd. ${ }^{10}$

Een ander belangrijk onderscheid is dat tussen contempt of court begaan ten overstaan van de rechter (contempt in the face of the court) en contempt of court die buiten de rechtszaal wordt gepleegd. De eerste categorie omvat een bont geschakeerde verzameling van gedragingen, variërend van beledigingen, ongepaste uitlatingen of andersoortige verstoringen van de orde ter zitting, misleiding van de rechtbank of het niet-voldoen aan verplichtingen, zoals de verplichting te verschijnen als getuige en vragen te beantwoorden. ${ }^{11} \mathrm{Bij}$ contempt of court die buiten de rechtszaal wordt begaan valt te denken aan het beïnvloeden van getuigen of juryleden, jurydelicten zoals het schenden van het geheim van de beraadslaging en het niet-naleven van rechterlijke bevelen, hoewel dit in strafzaken maar een zeer bescheiden rol speelt. ${ }^{12}$

Een belangrijke vorm van contempt of court buiten de rechtszaal is de zogenoemde contempt by publication, op grond waarvan het strafbaar is uitlatingen te doen of te publiceren waarmee een lopende procedure ernstig kan worden beinvloed of belemmerd. ${ }^{13}$ Het belang van deze bepaling is met name gelegen in het waarborgen van een eerlijke juryberechting, door te voorkomen dat juryleden in de media kennis kunnen nemen van informatie die niet voor het bewijs wordt gebruikt. Daarbij valt bijvoorbeeld te denken aan informatie over het strafrechtelijk verleden van een verdachte. ${ }^{14}$ Het contempt-recht biedt niet alleen de mogelijkheid om achteraf een vervolging in te stellen naar aanleiding van dergelijke publicaties, maar kan onder omstandigheden ook worden gebruikt voor het vooraf uitvaardigen van (tijde-

9. Bij de hiernavolgende bespreking wordt - tenzij anders aangegeven uitgegaan van het contempt-recht van Engeland en Wales.

10. D. Eady \& A.T.H. Smith, Arlidge, Eady \& Smith on Contempt, Londen: Sweet \& Maxwell 2011, p. 148.

11. C.J. Miller \& D. Perry, Miller on Contempt of Court (4th Edition), Oxford: Oxford University Press 2017, p. 10.

12. Miller \& Perry 2017, p. 11 en 163-164.

13. In Engeland en Wales is dit delict inmiddels neergelegd in de strafbepaling van art. 2 lid 2 Contempt of Court Act 1981.

14. Att Gen v ITV Central Ltd [2008] EWHC 1984 (Admin), [2008] All Er (D) 192 lijke) publicatieverboden. ${ }^{15} \mathrm{Op}$ dit punt zijn overigens wel grote verschillen te zien in verschillende common lam-landen. Zo bestaat in de Verenigde Staten in de praktijk geen contempt by publication. Dat hangt samen met het feit dat het recht op vrijheid van meningsuiting daar zeer ruim wordt uitgelegd. Wanneer de jury moet worden beschermd tegen al te uitgesproken publiciteit kiest men daar eerder voor andere maatregelen, zoals afzondering van de jury. ${ }^{16}$ Een specifieke vorm van contempt by publication is het delict van scandalising, op grond waarvan het strafbaar is om uitlatingen te doen waarmee ernstig afbreuk wordt gedaan aan de autoriteit van de rechtspraak. ${ }^{17}$ De strafbaarstelling is in Engeland in 2013 echter afgeschaft, omdat men deze onverenigbaar achtte met het recht op vrije meningsuiting. ${ }^{18}$ In andere common law-landen bestaat het delict nog wel.

Contempt of court kent van oudsher een afwijkende procedure, waarbij de rechter de verdachte op eigen initiatief in beschuldiging kan stellen en direct tot bestraffing kan overgaan, de zogenoemde summiere procedure. Omdat een dergelijke procesvoering niet onproblematisch is in het licht van de eerlijkprocesvereisten, wordt deze procedure tegenwoordig gereserveerd voor gevallen waarin direct ingrijpen noodzakelijk wordt geacht, veelal in gevallen van contempt in the face of the court. ${ }^{19}$ Daarbij dient de verdachte wel in de gelegenheid te worden gesteld zijn verdediging voor te bereiden en daartoe rechtsbijstand te zoeken. ${ }^{20}$ In andere gevallen vindt de vervolging doorgaans plaats in een afzonderlijke procedure. In Engeland en Wales kent contempt of court tegenwoordig een in de wet neergelegd strafmaximum van twee jaar gevangenisstraf of een (onbeperkte) geldboete. $^{21}$

Vanwege het gegeven dat contempt of court een inbreuk maakt op de uitingsvrijheid, wordt de toepassing ervan tegenwoordig vooral gerechtvaardigd geacht ter waarborging van een eerlijk proces en een ordelijke procesgang. Contempt of court is dus niet (meer) bedoeld om de rechtspraak voor kritiek te behoeden. Het feit dat de rechter een duidelijk herkenbaar instrument heeft om de orde te handhaven en om de naleving van zijn bevelen af te dwingen draagt uiteraard wel bij aan het gezag van de rechtspraak.

15. Vgl. art. 4 lid 2 en art. 11 Contempt of Court Act 1981

16. A. Ward, 'Freedom of the Press and Contempt of Court: A Comparison of the English and U.S. Law', Journal of Media Law and Practice 1982, 3, 2, p. 175-196; M. Chesterman, 'OJ and the Dingo: How Media Publicity Relating to Criminal Cases Tried by Jury is Dealt With in Australia and America', The American Journal of Comparative Law 1997, 45, p. 126-127.

17. $\mathrm{R} \vee$ Gray [1900] $2 Q B$ 36, 40: '( $\ldots)$ any act done or writing published calculated to bring a Court or a judge of the Court into contempt, or to lower his authority.'

18. Afgeschaft met art. 33 Crime and Courts Act 2013, in navolging van het advies van de Law Commission uit 2012: Report no. 335. Contempt of Court: Scandalising the court (raadpleegbaar via de website van de Law Commission).

19. Eady \& Smith 2011, p. 1103

20. Zie voor de processuele voorschriften van de summiere procedure in Engeland en Wales Part 48 van de Criminal Procedure Rules 2015.

21. Art. 14 lid 1 Contempt of Court Act 1981 
Voor een goed begrip van de betekenis van contempt of court is nog van belang te vermelden dat er tegenwoordig ook allerlei andere instrumenten zijn die op enigszins vergelijkbare wijze een bijdrage leveren aan de waarborging van de due administration of justice. Daarbij valt te denken aan de strafbaarstelling van meineed, (pogingen tot) het beïnvloeden, intimideren of omkopen van juryleden, getuigen of de rechter, en het typisch Angelsaksische delict van perverting the course of justice. Dat delict vertoont enige gelijkenis met contempt of court, maar omvat ook de periode vóór en na een gerechtelijke procedure. Vervolging vindt, anders dan bij contempt of court, plaats in een 'gewoon' strafproces. Bovendien kent Engeland een in de praktijk nageleefde $s u b$ judice-regel, op grond waarvan parlementariërs zich onthouden van het becommentariëren van zaken die onder de rechter zijn. ${ }^{22}$ Die sub judice-regel wordt door het parlement zelf gehandhaafd en wordt beschouwd als de parlementaire tegenhanger van contempt by publication.

\section{Contempt of court als inspiratiebron voor Nederland?}

Voor het beantwoorden van de vraag of contempt of court ook voor Nederland een meerwaarde kan hebben is het van belang om stil te staan bij de specifieke context waarin contempt of court zich heeft ontwikkeld en functioneert. Het instrument omvat een uitgebreid stelsel van door de eeuwen heen in de rechtspraak uitgekristalliseerde materiële en procedurele voorschriften. De politieke, constitutionele en maatschappelijke context en de karakteristieken van het Nederlandse straf(proces)rechtelijke stelsel zijn op veel punten anders dan in de Angelsaksische landen. In het bijzonder kan worden gewezen op het legaliteitsbeginsel en het feit dat de rechtspraak uitsluitend in handen is van professionele rechters. Het simpelweg overnemen van het common law-instrument van contempt of court stuit daarom niet alleen op praktische bezwaren, maar zou ook neerkomen op het implementeren van een zogenoemde legal transplant ${ }^{23}$ zonder acht te slaan op de maatschappelijke en juridische realiteit.

Daarbij komt dat contempt of court een zeer veelvormig instrument is. Wanneer in Nederland discussie wordt gevoerd over de vraag of we contempt of court moeten invoeren lijkt voor die veelvormigheid te weinig oog te zijn. Juist omdat contempt of court zo veel verschijningsvormen kent, zal de discussie over invoering van een

22. De sub judice resolution van de House of Commons, gepubliceerd in Hansard, HC Deb 15 November 2001 vol. 34 cc 1012-21 (online te raadplegen); en de House of Lords, HL Deb 11 May 2000 vol. 612 cc 1725-34.

23. D.w.z. het implementeren van praktische oplossingen in de vorm van vreemde rechtsfiguren die elders kennelijk werken, vgl. C.H. Brants, 'Strafrechtsvergelijking', DD 2008/16, p. 214-242, i.h.b. p. 222 vergelijkbare bepaling zich noodzakelijkerwijs moeten concentreren op de specifieke elementen die daar onderdeel van uitmaken. Gelet op de kenmerken van het Nederlandse stelsel ligt het dan voor de hand te kiezen voor invoering van specifieke, voldoende omlijnde (straf)bepalingen.

Contempt of court is bovendien een instrument dat 'slechts' kan worden ingezet in een lopende procedure met het oog op het garanderen van een goede rechtspleging in die betreffende zaak. Contempt of court leent zich er niet dus niet voor in meer algemene zin de rechtspleging te behoeden voor potentiële bedreigingen die buiten een concrete strafzaak om gaan. Bovendien wordt het instrument beschouwd als een tamelijk vergaande maatregel die alleen moet worden ingezet wanneer dat echt noodzakelijk is voor de waarborging van een goede strafrechtspleging. ${ }^{24}$ De legitimering ervan is tegenwoordig dan ook met name gelegen in het garanderen van een eerlijk en ordelijk procesverloop, en niet (in de eerste plaats) in het waarborgen van het gezag van de rechtspraak.

Al met al betekent dit dat contempt of court wel een inspiratiebron kan zijn voor het denken over de waarborging van de goede rechtspleging in Nederland, maar zich niet goed leent voor eenvoudige implementatie. Een zinvolle discussie over de meerwaarde van een contempt of court-achtig instrument is slechts mogelijk wanneer die wordt geconcretiseerd en toegespitst op de beweerdelijke problemen waarvoor het instrument een oplossing zou moeten bieden. De discussie zou zich, met andere woorden, moeten richten op de eventuele lacunes in de Nederlandse regeling en de vraag of in specifieke situaties aanpassing van de regeling met al dan niet op contempt of court geinspireerde instrumenten moet worden overwogen.

\section{Lacunes in de Nederlandse regeling}

Hoewel in Nederland geen contempt of court-bepaling bestaat, kent het straf(proces)rechtelijke stelsel een grote verscheidenheid aan instrumenten die dienen ter waarborging van een goede rechtspleging. Zo staan de rechter verschillende mogelijkheden ten dienste om de orde ter zitting te handhaven, heeft hij allerlei instrumenten om de rechterlijke waarheidsvinding te bevorderen en bestaan er strafbepalingen voor bepaalde gevallen van niet-naleving van rechterlijke beslissingen. ${ }^{25}$ Ook zonder het gehele arsenaal van mogelijkheden hier te behandelen, kan worden geconstateerd dat de Nederlandse regeling op bepaalde aspecten een minder ruim bereik kent dan het hiervoor op hoofdlijnen

24. Eady \& Smith 2011, p. 824.

25. Zie voor een uitgebreidere beschrijving van de in Nederland bestaande waarborgen ook M. Lochs, 'Verschijningsvormen van contempt of court in Nederlandse context', Strafblad 2017/79, afl. 6, p. 513-519. 
geschetste instrument van contempt of court. Hierna zal worden ingegaan op een viertal van deze aspecten en wordt bezien of en, zo ja, op welke wijze het instrumentarium al dan niet aanvulling zou behoeven. ${ }^{26}$

\subsection{Geen eigen punitieve bevoegdheid}

De Nederlandse strafrechter heeft, anders dan zijn Angelsaksische collega, geen punitieve bevoegdheid die hij op eigen initiatief kan inzetten wanneer de goede strafrechtspleging ter zitting dreigt te worden belemmerd. Hij is bijvoorbeeld voor de toepassing van het straf- en tuchtrecht afhankelijk van het openbaar ministerie respectievelijk de tuchtrechter. Toch kan bij beschouwing van de instrumenten die de rechter wél heeft niet worden geconstateerd dat aanvullende normering noodzakelijk is. Zo kan hij personen die een goed verloop van de zitting hinderen uit de zittingszaal laten verwijderen en voorzorgsmaatregelen treffen om mogelijke ordeverstoringen te voorkomen. ${ }^{27}$ Hij kan - sonder bepaalde voorwaarden - ingrijpen wanneer hij meent dat procesdeelnemers de grenzen van hun uitingsvrijheid overschrijden. ${ }^{28}$ De strafbepaling van belediging (art. $266 \mathrm{Sr}$ ) bepaalt daarbij de ondergrens van wat toelaatbaar is. Voor advocaten biedt daarnaast het tuchtrecht aanvullende normering. Op grond van hun verplichting zich te gedragen zoals een behoorlijk advocaat betaamt (art. 46 Advocatenwet) dienen zij zich onder meer te onthouden van ongepaste opmerkingen over rechters. Tegen ordeverstoringen kan ook strafrechtelijk worden opgetreden met de strafbaarstelling van het veroorzaken van opschudding ter zitting (art. $185 \mathrm{Sr}$ ), hoewel dat in de praktijk zelden of nooit wordt toegepast.

Er is al met al voorzien in zo veel andere instrumenten voor de handhaving van de orde ter terechtzitting dat niet van een gebrek aan waarborgen kan worden gesproken. Bovendien bestaat niet de indruk dat in de zittingszalen sprake is van een problematisch gebrek aan gezag of dat de rechter zich op grote schaal geen raad zou weten met ordeverstorende procesdeelnemers. ${ }^{29}$ Daarbij komt dat punitief optreden van de rechter in zijn 'eigen zaak' niet onproblematisch is. Hoewel het Europese Hof voor de Rechten van de Mens (EHRM) aanvaardt dat rechters maatregelen moeten kunnen nemen om de orde

26. In deze bijdrage wordt niet ingegaan op het fenomeen misbruik van procesrecht. Hoewel ook dat regelmatig met contempt of court in verband wordt gebracht maakt het in feite namelijk geen onderdeel uit van het contempt-recht. Zie voor een uitgebreidere bespreking Lochs 2019, p. 295-318 en 363-371.

27. Op grond van art. 124 lid 2 Sv

28. Zo heeft de verdediging niet het recht onbeperkt het woord te voeren, vgl. HR 26 mei 2015, NJ 2015/299 m.nt. Rozemond, en kan het laatste woord van de verdachte worden afgekapt bij langdradige, irrelevante of provocerende uitweidingen, vgl. HR 10 november 2015, ECLI:NL:HR: 2015:3266

29. Grimmelikhuijsen voerde een empirisch onderzoek uit onder rechters naar de vraag of zij een legitimiteitsprobleem ervaren en kwam tot de conclusie dat rechters niet per definitie in de rechtszaal zelf een sterk veranderende legitimiteit ervaren, maar dat zij wel het idee hebben dat de legitimiteit van de rechtspraak op maatschappelijk niveau veranderd is. Zie S. Grimmelikhuijsen, 'Van gegeven naar verdiend gezag', Rechtstreeks 2018/2, p. 13-35. ter zitting te handhaven, ${ }^{30}$ kan het recht op een eerlijk proces bij contempt-zaken in het geding komen. Zo oordeelde het EHRM in de zaak Kyprianou, waarbij een advocaat in een contempt-procedure was veroordeeld omdat hij de rechters ervan had beticht tijdens de zitting 'liefdesbrieven' uit te wisselen, dat sprake was van een schending van artikel 6 EVRM. Het Hof stelde vast dat de rechters, die zelf het onderwerp waren van de door Kyprianou geuite kritiek, de beslissing namen om te vervolgen, de zaak inhoudelijk behandelden, de schuld vaststelden en een straf oplegden. De daarmee gepaard gaande vermenging van de rol van benadeelde, getuige, aanklager en rechter was op zichzelf voldoende voor gerechtvaardigde twijfel aan de onpartijdigheid. ${ }^{31}$ De summiere contempt-procedure zal in de ogen van het EHRM dus al snel in strijd komen met artikel 6 EVRM. De in Nederland reeds bestaande waarborgen voor de waarborging van een ordelijk procesverloop ter zitting verdienen daarom met het oog op een eerlijke procesvoering de voorkeur.

\subsection{Geen algemene bevoegdheid om nakoming rechterlijke opdrachten af te dwingen}

Hoewel het niet-naleven van rechterlijke uitspraken in enkele specifiek genoemde gevallen strafbaar is gesteld, ${ }^{32}$ ontbeert de Nederlandse strafrechter een algemene bevoegdheid om de nakoming van zijn uitspraken of opdrachten af te dwingen. Waar het gaat om verdachten of advocaten die opdrachten niet uitvoeren, is het ontbreken van een specifiek instrument nauwelijks een probleem. Het is immers de officier van justitie en in beginsel niet (de advocaat van) de verdachte die gehouden is bepaalde informatie in opdracht van de rechter in het geding te brengen. Voldoet de advocaat niet aan door de rechter in het kader van de orde ter zitting gegeven opdrachten dan kan het tuchtrecht uitkomst bieden. Een openlijke weigering om gevolg te geven aan een door de rechter gegeven opdracht zal onder omstandigheden namelijk ook als een gebrek aan eerbied kunnen worden opgevat, en daarmee als een handelen dat niet overeenkomstig is hetgeen een behoorlijk advocaat betaamt. ${ }^{33}$

Een meer problematisch gebrek aan handhavingsmogelijkheden bestaat echter wel waar het gaat om het afdwingen van de naleving van rechterlijke opdrachten door het openbaar ministerie. Het openbaar ministerie is op grond van artikel $553 \mathrm{~Sv}$ weliswaar gehouden rechterlijke beslissingen ten uitvoer te leggen, maar die bepaling ziet slechts op onherroepelijke uitspraken en

30. EHRM 23 maart 1994, appl.no. 14220/88 (Ravnsborg v. Sweden), par. 34.

31. EHRM 15 december 2005, appl.no. 73797/01 (Kyprianou v. Cyprus), par. 127-128

32. Te denken valt aan art. $195 \mathrm{Sr}$, waarin strafbaar is gesteld het uitoefenen van een recht waarvan men bij onherroepelijke rechterlijke uitspraak is ontzegd; en art. 9 lid 1 WVW 1994, kort gezegd het rijden na een onherroepelijke rijontzegging.

33. Vgl. Hof van Discipline van 23 mei 2005, nr. 4232 
bevelen tot voorlopige hechtenis, ${ }^{34}$ en niet op andersoortige opdrachten zoals het toevoegen van stukken, het oproepen van getuigen of het verrichten van nader onderzoek. Hoewel ook in die gevallen een plicht tot uitvoering wordt aangenomen, ${ }^{35}$ voorziet de wet slechts in één geval in sanctionering: wanneer de officier van justitie weigert een getuige op te roepen aan wie anonimiteit is toegezegd, die door de rechter niet als bedreigde getuige is aangemerkt, wordt hij niet-ontvankelijk verklaard (art. 349 lid $3 \mathrm{~Sv}$ ). In de rechtspraak doen zich met enige regelmaat gevallen voor waarin het openbaar ministerie weigert dan wel nalaat een andersoortige rechterlijke opdracht adequaat uit te voeren. ${ }^{36}$ De sanctie van niet-ontvankelijkverklaring blijkt dan vrijwel steeds een te zwaar middel. ${ }^{37}$ En hoewel wellicht niet kan worden gesproken van een structureel probleem, moet worden geconstateerd dat de rechter in dergelijke gevallen feitelijk geen instrument heeft om de nakoming van zo'n opdracht af te dwingen. Dat gebrek aan mogelijkheden kan met het oog op de waarborging van een goede strafrechtspleging zeer problematisch zijn. Een openlijke weigering om aan de opdrachten van de rechter gevolg te geven tast immers de beslissingsmacht en het gezag van de rechter aan. Bovendien kan de rechterlijke waarheidsvinding ernstig worden belemmerd en maakt het inbreuk op de interne openbaarheid van het strafproces en daarmee op de in artikel 6 EVRM neergelegde verdedigingsrechten.

Een uitbreiding van het instrumentarium van de rechter op dit punt is dus wenselijk. Een op civil contempt geinspireerde strafbepaling voor de officier van justitie laat zich niet goed denken. Wel kan een oplossing worden gezocht in de introductie van een bepaling in het Wetboek van Strafvordering. Dat kan een bepaling zijn die vergelijkbaar is met het huidige artikel 349 lid $3 \mathrm{~Sv}$. Die niet-ontvankelijkheid maakt geen definitief einde aan de zaak en laat dus de mogelijkheid bestaan dat de vervolging wordt voortgezet wanneer het openbaar ministerie alsnog aan zijn verplichting heeft voldaan. Bovendien is de niet-ontvankelijkverklaring toetsbaar in hoger beroep en cassatie. ${ }^{38}$ Het verdient aanbeveling de mogelijk-

34. HR 24 mei 1991, NJ 1991/646; HR 1 juni 1999, NJ 1999/567 m.nt. Schalken; HR 31 oktober 2003, NJ 2005/196 m.nt. EAA; HR 14 oktober 2011, ECLI:NL:HR:2011:BR3058.

35. Vgl. MvT bij de Wet getuigenbescherming, Kamerstukken I/ 1991/92, 22483, 3, p. 29. Zie ook HR 25 juni 2002, NJ 2002/518 en de noot onder dit arrest van Schalken.

36. Bijv. Rb. Noord-Nederland 26 november 2013, ECLI:NL:RBNNE: 2013:7250 (ook 7261 en 7264); Rb. Limburg 11 oktober 2013, ECLI:NL:RBLIM:2013:7594 en (in hoger beroep) Hof Den Bosch 12 november 2015, ECLI:NL:GHSHE:2015:4516; en Rb. Alkmaar 16 november 2009, ECLI:NL:RBALK:2009:BK3440, NJ 2010/277 m.nt. Schalken en (in hoger beroep) Hof Amsterdam 25 oktober 2010, ECLI:NL:GHAMS:2010:BO1660

37. Vgl. Rb. Limburg 2 april 2014, ECLI:NL:RBLIM:2014:3022 en in hoger beroep Hof Den Bosch 26 mei 2015, ECLI:NL:GHSHE:2015:1855; en Hof Amsterdam 31 augustus 2009, ECLI:NL:GHAMS:2009:BJ7026 en de beslissing in cassatie HR 12 juli 2011, NJ 2011/381.

38. Beide aspecten waren destijds voor de wetgever de reden om art. 349 lid 3 Sv op de huidige wijze vorm te geven en te kiezen voor de sanctie van niet-ontvankelijkheid, zie MvT, Kamerstukken I/ 1991/92, 22483, 3, p. 29 heden te onderzoeken van een vergelijkbare bepaling voor gevallen van niet-naleving van rechterlijke opdrachten. Bij de vormgeving daarvan kan worden gedacht aan een bepaling die inhoudt dat de officier van justitie niet-ontvankelijk wordt verklaard wanneer hij weigert of in gebreke blijft opdrachten van de rechter uit te voeren, terwijl dat naar het oordeel van de rechter een ernstig verzuim oplevert en strijdig is met de beginselen van een behoorlijke procesorde en/of het recht op een eerlijk proces.

\subsection{Publiciteit rondom strafzaken}

In vergelijking met contempt of court is de publiciteit waarmee de grotere strafzaken vaak zijn omgeven in Nederland maar beperkt gereguleerd. De strafbepalingen van belediging, smaad en laster bepalen weliswaar de ondergrens van wat aan uitlatingen over zulke zaken en de daarin optredende actoren toelaatbaar is, maar kunnen mediaprocessen - met voor verdachten, rechters of de rechtspleging in het algemeen mogelijk schadelijke effecten - niet voorkomen. Het openbaar ministerie is gehouden aan de onschuldpresumptie en de eigen richtlijnen over publieksvoorlichting, ${ }^{39}$ en leden van het openbaar ministerie zijn, net als advocaten, gebonden aan hun geheimhoudingsplicht, die strafrechtelijk is gesanctioneerd (art. $272 \mathrm{Sr}$ ). Het tuchtrecht biedt voor advocaten ondersteunende regulering, maar de strafrechter heeft zelf weinig adequate mogelijkheden om overvloedige aandacht voor een strafzaak te beperken of daaraan in het strafproces gevolgen te verbinden. Dat geldt ook ingeval politici zich met een lopend proces bemoeien. ${ }^{40}$ De praktijk laat zien dat de rechter in dergelijke gevallen hoogstens strafvermindering toepast om de geschonden belangen van de verdachte te compenseren. ${ }^{41}$ Een adequate remedie kan dat bezwaarlijk worden genoemd.

De Engelse contempt by publication en de daarmee samenhangende publicatieregels bieden veel striktere normering. Voor dat verschil bestaat echter een duidelijke reden, nu de rechtvaardiging voor contempt by publication in Engeland vrijwel uitsluitend wordt gezocht in het garanderen van een eerlijke juryberechting. Daarmee ontbreekt in Nederland de belangrijkste grond voor invoering van een dergelijke bepaling en moet dit als een niet-noodzakelijke en te vergaande beperking van de persvrijheid worden beschouwd. Daarbij is ook van belang dat het EHRM ervan uitgaat dat een professionele rechter door zijn opleiding en ervaring in staat is om informatie uit de media bij zijn

39. Bijv. de Aanwijzing voorlichting opsporing en vervolging, 10 april 2012, Stcrt. 2012, 8161 en de Aanwijzing opsporingsberichtgeving, 16 februari 2009, Stcrt. 2009, 51.

40. Van een in de praktijk consequent nageleefde sub judice-regel (op grond waarvan politici zich onthouden van commentaar op een lopende zaak) is in Nederland geen sprake. Zie H. Gommer, Onder de rechter, Nijmegen: Wolf Legal Publishers 2008, p. 178-183 en 217-218.

41. Bijv. Rb. Haarlem 21 december 2007, ECLI:NL:RBHAA:2007:BC0703 (Holleeder). 
oordeelsvorming buiten beschouwing te laten. ${ }^{42}$ Het EHRM acht het dan ook onwaarschijnlijk dat grote media-aandacht gevolgen zal hebben voor de onpartijdigheid wanneer sprake is van berechting door professionele rechters. ${ }^{43}$ Bovendien is de wijze waarop de Britse en de Nederlandse media over strafzaken publiceren wezenlijk anders. Met name de Engelse tabloid-pers is berucht om de sensationele wijze van verslaggeving, waarin veel meer (persoonlijke) informatie wordt gedeeld dan gebruikelijk is in Nederland.

De constatering dat een strafbepaling zoals contempt by publication een te vergaande maatregel is, maakt overigens nog niet dat er op de Nederlandse situatie niets valt aan te merken. Ook zonder dat sprake is van een jurysysteem kan het met het oog op de waarborging van een goede strafrechtspleging wenselijk zijn als meer dan thans het geval is kan worden voorkomen dat (in een vroeg stadium) wordt gepubliceerd of geciteerd uit een strafdossier. Waar ingrijpen van de overheid een te vergaand middel is, ligt er in de eerste plaats een taak voor de journalistiek zelf. Persvrijheid brengt immers ook verplichtingen met zich mee. In de Leidraad voor de Fournalistiek wordt onder meer als uitgangspunt genomen dat journalisten het belang dat met een publicatie is gediend, afwegen tegen de belangen die eventueel door de publicatie worden geschaad. ${ }^{44}$ De belangen van een goede strafrechtspleging lijken in de door journalisten te maken afweging van wat er al dan niet wordt gepubliceerd, echter nauwelijks een rol te spelen. ${ }^{45}$ Het zou daarom goed zijn wanneer die belangen, vaker of nadrukkelijker dan nu het geval is, in de afweging worden betrokken. Dat geldt eens te meer wanneer informatie bij de journalist terecht is gekomen die naar alle waarschijnlijkheid in strijd met de geheimhoudingsplicht is verstrekt. Het klakkeloos gebruiken van die - in feite door misdrijf verkregen - informatie verhoudt zich niet goed met de verplichtingen die de keerzijde vormen van de aan de journalist toekomende vrijheden en privileges. Om een dergelijke cultuuromslag te kunnen bewerkstelligen is een sterkere positie van de Raad voor de Journalistiek wel een vereiste. ${ }^{46}$

In de tweede plaats zou het vanuit het perspectief van een goede strafrechtspleging goed zijn als politici grotere terughoudendheid betrachten bij het doen van

42. EHRM 20 december 2011, appl.no. 20899/03 (G.C.P. v. Romania), par. 48. Zie ook EHRM 30 juni 2009, appl.nos. 75109/01 + 12639/02 (Viorel Burzo v. Romania), par. 166; EHRM 18 februari 2016, appl.nos. $6091 / 06+4047 / 07+4070 / 07$ (Rywin v. Poland)

43. Zie met zoveel woorden, EHRM 30 juni 2015, appl.no. 30971/12 (Abdulla Ali v. UK), par. 88

44. Leidraad van de Raad voor de Journalistiek 2018, onder 'A. Uitgangspunten'.

45. Zie ook C.H. Brants, 'Trial by media: publiciteit in het vooronderzoek', in: A.H.E.C. Jordaans, P.A.M. Mevis \& J. Wöretshofer, Praktisch strafrecht (liber amicorum J.M. Reijntjes), Nijmegen: Wolf Legal Publishers 2005, p. 45-61, i.h.b. p. 51-56.

46. Zie over het functioneren van de Raad uitgebreider J. Mentink, Veel raad, weinig baat. Een onderzoek naar nut en noodzaak van de Nederlandse Raad voor de Journalistiek (diss. Leiden), Rotterdam: Ad. Donker 2006 uitlatingen over lopende rechtszaken. De vrijheid die politici zich in Nederland soms permitteren kan de rechter in een lastig parket brengen. Het kan in concrete zaken aanleiding geven tot verweren over de eerlijkheid van het proces, in het bijzonder de onschuldpresumptie. ${ }^{47}$ Uitlatingen van politici over lopende zaken kunnen ook de indruk doen ontstaan dat de rechter onder politieke druk staat om tot een bepaalde beslissing te komen en kunnen daarmee afbreuk doen aan de (gepercipieerde) onafhankelijkheid van de rechter. ${ }^{48}$ Wanneer veelvuldig kritiek wordt geuit op bepaalde aspecten van de rechtspleging (bijvoorbeeld te lage straffen) kan dat ook meer in algemene zin negatief doorwerken, doordat daarmee het vertrouwen in en het gezag van de rechtspraak in het algemeen worden aangetast. Een aanscherping van de sub judice-regel naar Engels voorbeeld verdient dan ook aanbeveling. Een dergelijk voorschrift kan worden neergelegd in het Reglement van Orde van de Eerste en Tweede Kamer, waarbij het parlement zelf toeziet op de naleving ervan. Hoewel een dergelijke inperking van de parlementaire uitingsvrijheid van politici een zelfbeheersing verlangt die in de huidige tijdsgeest wellicht niet voor de hand ligt, is een discussie hierover wenselijk. Juist in tijden waarin de positie van de rechtspraak in andere (EU-)landen onder druk komt te staan, is het immers van belang dat de verschillende staatsmachten samen hun verantwoordelijk nemen om de rechtsstaat te (blijven) waarborgen. ${ }^{49}$

\subsection{Het gezag van de rechtspraak}

Wanneer naar de Nederlandse contempt-achtige instrumenten wordt gekeken, valt op dat er in feite niet veel concrete instrumenten zijn die primair zijn gericht op waarborging van het gezag of de legitimiteit van de strafrechtspraak. De strafbepalingen van het niet-naleven van rechterlijke uitspraken kunnen tot op zekere hoogte in deze categorie worden geschaard, net als de strafbepaling van belediging en smaad en het tuchtrecht, voor zover het de advocatuur eerbied voor de rechterlijke autoriteiten oplegt. Deze instrumenten zien echter slechts op specifieke personen of situaties en lijken niet bedoeld om het gezag van de rechtspraak in het algemeen te waarborgen. Het is niettemin juist de meer algemene 'ondermijning' van het gezag van de rechtspraak die vaak wordt genoemd als reden voor het invoeren van contempt of court. Hoewel het vertrouwen in de rechtspraak op zichzelf tamelijk hoog is, ${ }^{50}$ wordt vaak gesignaleerd dat het gezag van de rechtspraak - net als van veel andere instituties - niet langer

47. Bijv. Hof Amsterdam 18 juli 2003, ECLI:NL:GHAMS:2003:AI0123 (Volkert van der G.).

48. Vgl. Rb. Den Haag 21 juni 2005, ECLI:NL:RBSGR:2005:AT7856.

49. Zie in die zin ook de nieuwjaarstoespraak van Frits Bakker, voormalig voorzitter van de Raad voor de rechtspraak, op 11 januari 2018, en meer recent de nieuwjaarstoespraak van Henk Naves, huidig voorzitter van de Raad voor de rechtspraak, op 9 januari 2020 (gepubliceerd op rechtspraak.nl).

50. Zie voor de meest recente cijfers SCP, Burgerperspectieven 2019/4, Den Haag: Sociaal Cultureel Planbureau 2018, p. 10-11. 
vanzelfsprekend is. ${ }^{51} \mathrm{Er}$ is in de rechtspraak dan ook veel aandacht voor de wijze waarop het vertrouwen van ook de kritische en mondige burger kan worden behouden. ${ }^{52}$

Voor zover in Nederland behoefte zou bestaan aan versterking van het gezag van de rechtspraak, lijkt contempt of court daarvoor in ieder geval geen geschikt middel. Daarvoor is van belang om te constateren dat contempt of court in Engeland in de eerste plaats wordt gezien als instrument om de goede rechtspleging - in het bijzonder een eerlijk proces en een ordelijk procesverloop - in een concrete zaak te garanderen. Waarborging van het gezag van de rechtspraak is niet (meer) het voornaamste doel van het contempt-recht. De afschaffing van het delict van scandalising the court, waarmee kon worden opgetreden tegen - kort gezegd - gezagsondermijnende kritiek op de rechtspraak, is daarvan een duidelijke illustratie. Tegen die achtergrond ligt de invoering van een scandalising-achtige bepaling in Nederland niet voor de hand. Daarbij komt dat ook niet direct van een noodzaak tot dergelijk, met het oog op de vrije meningsuiting tamelijk drastisch, ingrijpen kan worden gesproken. Hoewel de rechtspraak - overigens net als andere instituties - inderdaad aan kritiek wordt blootgesteld, blijft die over het algemeen toch redelijk binnen de perken. 'Amerikaanse taferelen' zoals we die kennen sinds het aantreden van Trump, zijn in Nederland in ieder geval (nog) niet aan de orde. ${ }^{53}$ Bovendien moet in ogenschouw worden genomen dat een scandalising-achtige strafbepaling wellicht de indruk kan doen ontstaan dat de rechtspraak zich krampachtig tegen het vrije woord probeert te weren en tracht om met een machtsmiddel critici te mond te snoeren. Dat zal het gezag van de rechtspraak vermoedelijk eerder schaden dan goed doen.

Deze conclusie is wat onbevredigend en laat onverlet dat de strafrechtspleging wel degelijk met uitdagingen te maken heeft. Hoewel contempt of court voor veel van dergelijke problemen, in het bijzonder ook waar het gaat om het gezag van de rechtspraak, geen geschikte oplossing blijkt, kan wel op andere wijzen worden getracht de positie van de strafrechter te versterken. Daarbij kan in de eerste plaats worden gewezen op het feit dat de rechter minder dan vroeger een centrale figuur is in de afdoening van strafzaken, onder meer door de toename van buitengerechtelijke afdoeningsmodaliteiten. De laatste jaren is van verschillende zijden en in uiteenlopende contexten gewezen op de daaraan klevende risico's en nadelen. ${ }^{54}$ Er kan dan ook met recht worden gepleit voor

51. Vgl. Grimmelikhuijsen 2018; C. Brinkgreve, 'Het tanende gezag van de toga. Essay De lijdende rechter', Recht der Werkelijkheid 2014, afl. 1, p. 84-89.

52. Zie bijv. D. Broeders e.a., Speelruimte voor transparantere rechtspraak (WRR-verkenning 26), Den Haag/Amsterdam: Amsterdam University Press 2013.

53. 'In His Own Words: The President's Attacks on the Courts', gepubliceerd op brennancenter.org.

54. Vgl. J.H. Crijns \& R.S.B. Kool, 'Afscheid van de klassieke strafrechtelijke procedure?', in: L.M. Coenraad e.a., Afscheid van de klassieke proce- het niet verder laten afkalven c.q. verstevigen van de rol van de rechter. Daarbij valt bijvoorbeeld te denken aan het door de Minister van Justitie en Veiligheid aangekondigde voornemen een regeling te treffen voor een rechterlijke toets van hoge transacties (de zogenoemde 'megaschikkingen'). ${ }^{55}$ Maar ook een verruiming van de mogelijkheden de vervolgingsbeslissing te toetsen ${ }^{56}$ en een duidelijker positionering van de actieve zittingsrechter $^{57}$ kunnen hieraan bijdragen. Ten tweede kan worden geconstateerd dat de laatste jaren veel nadruk is gelegd op de dienstverlenende taak van de rechtspraak. Er is veel aandacht voor productiviteit, efficiëntie en transparantie en door middel van klantwaarderingsonderzoeken worden de wensen en opvattingen van 'klanten' van de rechtspraak in beeld gebracht. ${ }^{58} \mathrm{Op}$ die 'klantgerichte' instelling en de (te) grote nadruk op het vermeende gezagsprobleem van de rechtspraak is kritiek gekomen. ${ }^{59}$ Met contempt of court en de wat minder 'tobberige' houding ${ }^{60}$ van de Angelsaksische rechter als inspiratie, kan worden gesteld dat gezag in de moderne tijd weliswaar niet vanzelfsprekend is, maar dat het 'verdienen' van dat gezag wellicht het beste kan gebeuren door zich te richten op de kerntaak in plaats van op de dienstverlenende functie van de rechtspraak. Ten derde kan worden onderstreept dat ook de andere staatsmachten een verantwoordelijkheid hebben voor de waarborging van de positie van de rechtspraak. Niet alleen zouden zij terughoudender moeten zijn met uitlatingen over zaken die onder de rechter zijn, zij zouden ook fermer stelling moeten nemen tegen ondermijnende acties en kritiek. ${ }^{61}$ De naar aanleiding van de uitspraken in de stikstof- en Urgenda-zaak (ook) door politici geuite ver-

dure? Preadviezen van de Nederlandse Juristenvereniging. Handelingen Nederlandse JuristenVereniging, 147e jaargang, 2017-I, Den Haag: Kluwer 2017, p. 314-320 en 339-342 en over de strafbeschikkingspraktijk van het $\mathrm{OM}$ de rapporten 'Beschikt en gewogen' en 'Beproefd verzet' van de procureur-generaal bij de Hoge Raad in het kader van het in art. 122 lid 1 Wet RO bedoelde toezicht.

55. Brief Minister van Justitie en Veiligheid d.d. 19 december 2018: Beleidsreactie rapport 'Evaluatie Wet OM-afdoening', p. 7-10

56. Zoals onder meer bepleit door Crijns \& Kool in hun NJV-preadvies en eerder door Y. Buruma, 'Rechterlijke controle op de vervolgingsbeslissing', Strafblad 2015/4, p. 314-322.

57. Zoals onder meer bepleit door M.J. Dubelaar \& J.M. ten Voorde, 'Toekomst voor de actieve zittingsrechter?', Expertise en Recht 2016, afl. 1, p. 4-11.

58. Zie uitgebreid over dergelijke invloeden E. Mak, De rechtspraak in balans. Een onderzoek naar de rol van klassiek-rechtstatelijke beginselen en 'new public management'-beginselen in het kader van de rechterlijke organisatie in Nederland, Frankrijk en Duitsland, Oisterwijk: Wolf Legal Publishers 2008.

59. Bijv. A.M. Hol, 'Rechtspraak. Tussen heteronomie en autonomie', in: M.W. van Boven \& P. Brood, Tweehonderd jaar rechters, Hilversum: Verloren 2011, p. 349-368, i.h.b. p. 365; T. Jansen \& A. Gabrielli, 'Theorie ontmoet praktijk. Handreikingen voor effectief modern gezag. Gesprek met Evelien Tonkens en Barend Rombout', in: T. Jansen, G. van den Brink \& R. Kneyber, Gezagsdragers. De publieke zaak op zoek naar haar verdedigers, Amsterdam: Boom 2012, p. 279-295, i.h.b. p. 288; het Rapport visitatie gerechten 2018, Goede rechtspraak, sterke rechtsstaat, 22 maart 2019, p. 39-41.

60. Zie voor het verwijt van 'tobben' in Nederlandse context ook G.J.M. Corstens, 'Vertrouwen in de rechtspraak', Trema 2011, afl. 10, p. 365-367.

61. Vgl. ook de Rechtspraaklezing van Lord Thomas, The future of the judge, the judge of the future - A keynote address, 2017. 
wijten dat de rechtspraak te zeer op de stoel van de wetgever zou gaan zitten, laten zien dat daarbij nog een lange weg te gaan is. Bovendien worden vanuit de rechtspraak al jarenlang zorgen uitgesproken over de werkdruk, financiering en organisatie van de rechtspraak. ${ }^{62}$ Het is mede aan de politiek om ervoor te zorgen dat de rechtspraak in organisatorisch en financieel opzicht in staat is haar essentiële rol in de samenleving te vervullen.

\section{Conclusie}

Contempt of court is een tot de verbeelding sprekend verschijnsel dat in Angelsaksische landen een belangrijke waarborg vormt voor een goede rechtspleging. Invoering van een Nederlandse variant van contempt of court is, gelet op de vaagheid en veelvormigheid van het begrip en de verschillende juridische en maatschappelijke context, echter niet goed mogelijk. Bovendien blijkt het Nederlandse instrumentarium ter waarborging van een goede strafrechtspleging op zichzelf reeds behoorlijk adequaat te zijn. Waar niettemin aanvullende waarborgen wenselijk zijn moet worden gekozen voor de invoering van specifieke, duidelijk omschreven (straf)bepalingen in plaats van een weinig omlijnd instrument zoals contempt of court. Bij nadere beschouwing van de Nederlandse situatie wordt in ieder geval een strafvorderlijke sanctie op het niet-uitvoeren van rechterlijke opdrachten door het openbaar ministerie aanbevolen. Daarnaast zouden journalisten zich bij hun verslaglegging meer gelegen moeten laten liggen aan de belangen van een goede strafrechtspleging. Gelet op het belang van persvrijheid is een strafbepaling echter te ingrijpend en moet daarvoor worden teruggegrepen op journalistieke zelfregulering. In het verlengde daarvan verdient implementatie van een sub judice-regel voor politici naar Engels voorbeeld aanbeveling. Hoewel contempt of court vaak is geopperd als mogelijkheid om het gezag van de rechtspraak te versterken, blijkt dat het instrument daarvoor maar beperkte betekenis kan hebben. Het strafbaar stellen van kritiek op de rechtspraak is in de huidige omstandigheden in ieder geval een te vergaande en onnodige maatregel. Dat neemt niet weg dat van vooral politici een andere opstelling mag worden verwacht, waarbij zij zich niet met kritiek tegen de rechtspraak keren, maar juist laten zien dat zij medeverantwoordelijk zijn voor het waarborgen van de rechtsstaat. 